\title{
Analysis of the spatiotemporal transformation of Fort San Domingo in Tamsui, Taiwan, from the perspective of cultural imagination
}

\author{
C.-Y. Chang \\ Ministry of the Interior, Architecture and Building Institute, \\ Taiwan, $R O C$
}

\begin{abstract}
The timeline of transformation of Fort San Domingo shows that between the 1630 s and 1860s it was used as a military defense; from the 1860s-1970s as a foreign consulate and then from the 1980s-2010s as a historical site. We can see different and contradictory explanations of the cultural imagination of remembrance, exoticism and the symbolism of anti-imperialism from the historical context of this military building.

Keywords: spatiotemporal transformation, Fort San Domingo, Tamsui, cultural imagination.
\end{abstract}

\section{Introduction}

Fort San Domingo is rather young compared to forts built in Europe, yet it has a different historical meaning for this island located in Eastern Asia. Fort San Domingo (聖多明哥城) was one of the earliest Grade I heritage sites first appointed under the Cultural Heritage Preservation Act in 1982. It is the most well preserved fortress that can be dated back to the golden age of expeditions made by the Dutch East India Company during the colonial era. Moreover, Fort San Domingo is also the first heritage that has been transformed into a modern museum. Named the Tamsui Historical Museum of New Taipei City, the fort and its surrounding historical buildings were listed as a Potential World Heritage Site in Taiwan by the Ministry of Cultural Heritage. 


\section{Methodology}

Past research on Fort San Domingo by Chang [1], Huang [2], Yin [3] and Li [4] aimed mostly at the aspects of architecture and history. I hope with my research to clarify the hidden meanings of Fort San Domingo by connecting the spatiotemporal transformation and its cultural imagining. Acknowledgement of the transformation of space and landscape is related to the cultural cognition of that age. The imagination of later generations will overlap onto the imagination, history, social context and the emotional response to one's living space of their predecessors. Anderson [5] once said that a nation is an "imagined community". As for related studies, Tuan [6] once proposed the concept of "Topophilia", a concept word consisting of "topo (place)" and "philia (love)", indicating that people recognize their place by an emotional connection with it rather than the cold scientific logic of spaces. Tuan [7] also mentioned that a "sense of place" is built by the experiences learned from their living environment during people's lifetimes. After time, people will have bonds toward their place and acquire a sense of security and belonging toward it. Space and place are interrelated; for space is created by immigration from one place to another while place needs space to exist. Cressswell [8] said that place is a method for seeing and knowing the world. You can discover a world of meanings and experiences by studying the relationship between people and their places. Cresswell quoted John Agnew's theory that there are three basic sides of space, which are "location", "place "and "sense of place". There are special orders in this world with social and geological bases, what we are fighting against is the decaying order of flowing memory in the human mind.

Another theory related to this paper is the relation between space and society. Lefebvre [9] said that "society is a product of space". Lefebvre's theory indicates that space is in relation with property (especially the owning of land) and related to the prolificacy of the land which forged its shape. Space is all about social relation. Space is not only supported by social relation but also produces social relation and is born in it.

This paper aims to analyze two aspects of the transformation of spatial use in Fort San Domingo and cultural imagination. The theory is that space is constructed during social development, so the structural form of space will present certain social power relations defined by history while imagination in literature will have meanings related to a sense of place. My research methods include analysis of historical documents and works of text. First, to organize the history of the transforming functions of Fort San Domingo and its form by studying old historical texts and modern research essays, and defining the spatial character of the building during every period. Second, to analyze approximately one hundred texts about Fort San Domingo chosen by myself from local chronicles of Tamsui (淡水) to literal works in every period and sorting them into major categories to analyze the characteristics of texts. 


\section{Research and results}

\subsection{Analysis of the spatiotemporal transformation of Fort San Domingo}

The Spanish built Fort San Domingo as a military expansion in northern Taiwan after they established Fort San Salvador in 1626 on Keelung's Hoping Island. Around 1629, they built Fort San Domingo in Tamsui, which was the farthest frontier of Spanish Formosa. It was originally built by Spanish colonists on the hill near the estuary of what is now Tamsui River and named "San Domingo". The Dutch rebuilt the fort and named it Fort San Antonio in 1644. Between the two centuries of the completion of Fort San Domingo and Columbus's discovery of America in the 15th century, European countries such as Portugal, Spain and the Dutch Republic were eager to find new colonies out of a desire for gold, silver, spices and other riches under the name of mercantilism. They were also trying to resolve the conflict between Catholics and Protestants by extending the battlefield overseas (Fig. 1). After the Dutch left the island, the fort was used as a barricade castle during the reign of the Kingdom of Tungning and the Qing government (c. 1680s-1850s). The Chinese officials of the Qing Government forbade anyone near the fort with the aim of preventing any potential rebellion.

After the Qing government opened trade to foreign countries, Fort San Domingo started to build relations with Tamsui. Before the opening of trade, Tamsui originally established a long-term economic cooperative relationship with mainland China, now it had become part of the world trade system because of its ability to provide products for international trading. Tamsui at that time was a free trading port for foreigners; they developed inhabitants outside the old city and were allowed to trade and reside permanently or temporarily. In 1867, the British government acquired the old Dutch fort and the lands nearby to build a new British Consulate office according to the "Treaty of Permanent Lease of Fort San Domingo" signed with the Qing government. In spatial usage, the British Consulate set its offices on the second floor and the Consul's office is in the east room of the same floor with a furnace inside. Outside the office is the accounting office with a huge safety vault and incinerator for papers. The outside rooms are offices for agents, consular assistants and interpreters. They made four small cells with brick walls and left more space for outside rooms for management use (Fig. 2). The fort has a cross vault with thick walls and a middle column to support its own weight. The interior wall splits the second floor into four simple square rooms, so there is an extreme contrast between the thick walls and its simplified space. Battlements were added to Fort San Domingo and a new terrace for defensive use while symbolizing a castle. As the wall looked red because of its butyrelite cover, people call it "Hong-mao castle" (紅毛城) meaning the Castle of Red Hair (Fig. 3) (Tab. 1). 
Table 1: Chronicle of spatiotemporal transformation of Fort San Domingo.

\begin{tabular}{|c|c|}
\hline Year & Important events \\
\hline c. $1629 \mathrm{CE}$ & $\begin{array}{l}\text { Spanish built a fort on the hill near estuary of what is now Tamsui River and } \\
\text { named it "San Domingo" [4]. }\end{array}$ \\
\hline 1642 & $\begin{array}{l}\text { In August, the Dutch defeated Spain and took San Domingo. They seemed to have } \\
\text { renamed the fort Fort Diemen in the name of the Governor-General of the Dutch } \\
\text { East Indies, Anthony van Diemen [10]. }\end{array}$ \\
\hline 1643 & $\begin{array}{l}\text { In July, the Governor of Formosa and council of the Dutch East India Company } \\
\text { decided to replace the fort with a stone castle [10]. }\end{array}$ \\
\hline 1644 & $\begin{array}{l}\text { The Dutch repaired the fortress and called it Fort San Antonio (聖安東尼奧城). } \\
\text { On the fort wall there was a half-moon shaped window. They called the (southern) } \\
\text { western point "Dieman", northeastern point "Maria" and the southern (eastern) } \\
\text { point "sulfur point" [10,11]. }\end{array}$ \\
\hline 1654 & $\begin{array}{l}\text { The Dutch sent men to repair Fort San Antonio. They took off the original } \\
\text { octagonal roof and replaced it with a platform covered with square stones and } \\
\text { lime. The slits and cracks between stones were filled with linseed oil and lime mud } \\
\text { to prevent leaks [10]. }\end{array}$ \\
\hline 1668 & $\begin{array}{l}\text { Dutch occupation of Taiwan ended. Fort San Antonio remained rather undamaged } \\
{[10] \text {. }}\end{array}$ \\
\hline $\begin{array}{c}1681 \text { or } \\
1683\end{array}$ & General He-you ordered the construction of the old wall [12]. \\
\hline 1724 & $\begin{array}{l}\text { Tamsui Sheriff Wang Qian ordered the construction of the east and west main gate } \\
\text { and south, north small gate as barracks. Today only the south gate remains [12]. }\end{array}$ \\
\hline 1813 & $\begin{array}{l}\text { The Qing army was garrisoned in Fort Pao of Tamsui and built batteries of } \\
\text { cannons [2]. }\end{array}$ \\
\hline 1867 & $\begin{array}{l}\text { The British government took over the entire fort by signing the "Treaty of } \\
\text { Permanent Lease for Fort San Domingo" with the Qing government. They } \\
\text { acquired a permanent lease of the old Dutch fort and the lands nearby for building } \\
\text { a new British Consulate office [13]. }\end{array}$ \\
\hline 1868 & The British Consulate moved to Fort San Domingo [14]. \\
\hline 1877 & Completion of the new British Consulate office $[14,15]$. \\
\hline 1900 & $\begin{array}{l}\text { The British Consulate ordered the construction of drinking water facilities and } \\
\text { running water [16]. }\end{array}$ \\
\hline 1912 & $\begin{array}{l}\text { The "Permanent Lease Treaty of Fort San Domingo" proposed by the British } \\
\text { Consulate was agreed to [16]. }\end{array}$ \\
\hline 1922 & Completion of lightbulbs and electric fans in the British Consulate [16]. \\
\hline 1932 & $\begin{array}{l}\text { Completion of a modern sewage system and hot water supply in the British } \\
\text { Consulate [16]. }\end{array}$ \\
\hline 1934 & Completion of the reconstruction of a staff dormitory in the British Consulate [16]. \\
\hline 1942 & The British Consulate closed due to war between Japan and the allied nations [12]. \\
\hline 1945 & The British returned to Fort San Domingo [1]. \\
\hline 1972 & $\begin{array}{l}\text { In March 21st, Britain broke off diplomatic relations with ROC. The British } \\
\text { Consulate in Fort San Domingo closed and was held in trust to the Australian } \\
\text { Embassy in China [1]. }\end{array}$ \\
\hline 1980 & The official transfer of Fort San Domingo to ROC [1]. \\
\hline 1983 & Appointed Grade I Heritage on December 18th [1]. \\
\hline 2003 & $\begin{array}{l}\text { In July, the Ministry of the Interior handed Fort San Domingo to Taipei county } \\
\text { government [1]. }\end{array}$ \\
\hline
\end{tabular}




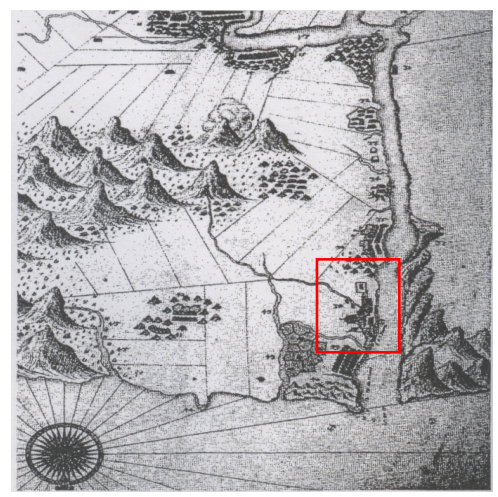

Figure 1: Fort San Antonio in Tamsui during Dutch rule (Red Square) [23].
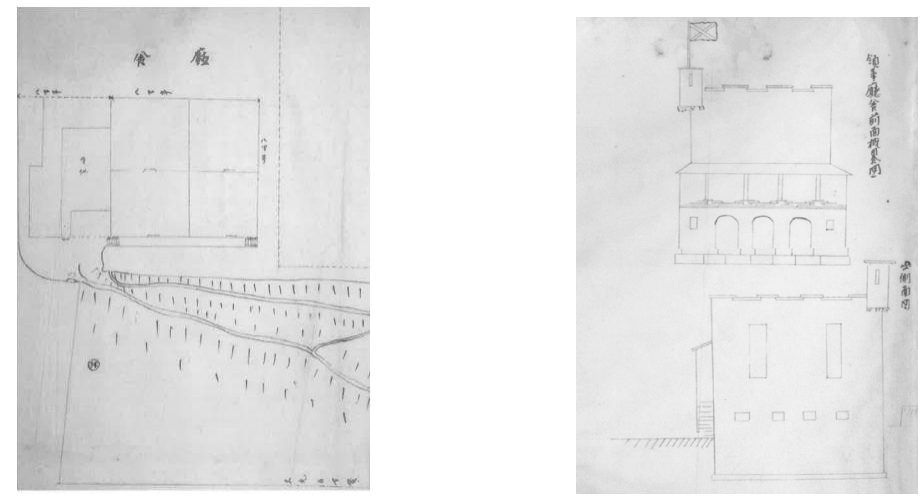

Figure 2: Drawings of Fort San Domingo in the late 19th century [25].

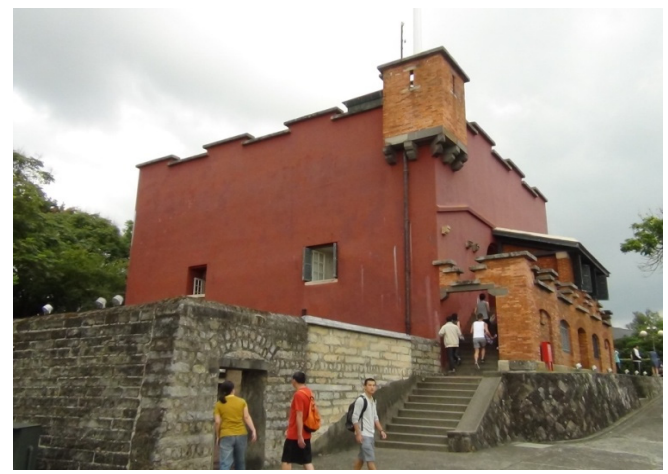

Figure 3: Fort San Domingo today (photo taken in 2015). 


\subsection{Analysis of the cultural imagination about Fort San Domingo}

\subsubsection{Imagination of Fort San Domingo in remembrance of history}

\subsubsection{Analysis of poems written by Lin Feng-yuan, Chou Zhong-xuan, Chen Wei-ying and Yang Jun during the Qing period}

Lin Feng-yuan’s (林逢源) poem about “the Sunset of Fort” (戊台夕陽):

"Fort built high above the water and clouds. A guest arrived in sunset time. Birds flew by like a line in the sky. Sails of six is my ship return. War torn fort left only walls. Smokes were up down the new village. Peace is now in every mountain and sea. Old man told the story of aged battle" [17].

This poem uses water, cloud, sunset, sky, birds, ship, war remnants, smoke, mountain and sea to describe the feeling of remembrance when seeing the remains of the Old Dutch fort.

Chou Zhong-xuan's (周鍾暄) poem about “the Tamsui Cannon Fort” (淡水 砲城):

"Estuary is like a narrow door. To hold it is the best defense. They wish to conquer and be King. A march north is what they planned. Fort is old now yet waves still pound. Coldness of seawater in mid-autumn. Wish to find answer with someone. Yet the girl is too young to know" [18].

Chou wrote this poem roughly 60 years after the Dutch occupation. He saw the broken ruins of the fort and recalled the military strategies of the past.

Chen Wei-ying's (陳維英) poem about “the Sunset of Fort” (戊台夕陽):

"Long time passed since they took it by leathers. I felt the sadness of history within. Just beside the old tree where a crow stands" [17].

This poem describes a sense of sorrow when Chen visited Fort San Domingo at sunset.

Yang Jun’s (楊浚) poem about “the Steam Ship of Tamsui” (滬口飛輪):

"The wake of a ship stretches a long way. I saw a sky filled with a lot of smoke. The Fort sounded the horn during sunset. On a dusty hill I watch the passing boats. New ship is not the same as my home. Maybe they envy us more. The wave is peaceful like a mirror I can paint. A painting of a fairyland with a bright sky" [17].

This poem describes the scenery of Tamsui like a painting scroll. He brings out the emptiness and sorrow of history by the image of a horn sounding at sunset at Fort San Domingo.

Overall, the cultural imagination of Fort San Domingo in the Qing period primarily comes from the connection of old Dutch remains, landscape, sunset and the idea of military defense. 


\subsubsection{Fort San Domingo as an image of legend}

The "Secret of Madam Liu" (劉夫人的祕密) was published in the 15th "Mazu" magazine on December 12th, 1937. In his book, Nishikawa (1908-1999) (西川 滿) tells the story of a man who had received a confession note of a Tamsui teen from the hospital director. The teen was obsessed with studying the ancient books from the Temple of the Heavenly Mother and found out that Madam Liu traded her virginity to the Dutch long ago for the knowledge of alchemy, which she later used to restore her family wealth. He threatened the descendent of Madam Liu for the knowledge of alchemy. When things were just about to get worse, Madam Liu walked out of the portrait and frightened the young teen with ease. The teen later went to an asylum for the rest of his life.

Nishikawa blended the belief in Mazu in his novel with some historical fiction from the story of the Spanish-Dutch period. It creates a dreamlike wonderland. He wrote, "Sunset time in Tamsui. I stand on the old batteries watching the splendid rainbow-like Guanyin Mountain and the white foggy smoke covering the entire street. I once heard of this magnificent scenery in Tokyo. However, one cannot believe this place exists. Now I stand before it with amazement in my heart. The resting sails and boats, Guanyin Mountain standing straight by the ocean. All this beauty I compared with the solemn beauty of Amitabha. I almost forgot my own existence. "It is Venice in the Orient" [19]. The old battery mentioned above is Fort San Domingo. He highlighted the difference of time and space between Guangyin Mountain and the street by watching them both on Fort San Domingo. His wrote down the feeling of amazement and imagined himself as Chinese while connecting the Guanyin Mountain to Amitabha expressing an idea from Japanese Shinto. Because Nishikawa is not restricted to the Chinese poem form, he could transform the image of Fort San Domingo and make stories to create a new legend. For a Japanese man like him, the traditional restraint of the Chinese is his resource for folklore and legends and helps him create a new perspective of imagination. $\mathrm{He}$ wrote, "I went to the cell of Fort San Domingo every day to meditate on the knowledge of alchemy" [19]. His book described a Chinese man who ran into Fort San Domingo imagining the legendary alchemy. Hoping to get treasure, he had plotted in the cell to threaten his friend. The connection of the main character to the prisoner in the cell is obvious.

Overall, Nishikawa transformed the image of Fort San Domingo and gave it a new story, thus creating a completely different aspect. He used the image of the Fort and the cell to construct his imagination of the legendary novel.

\subsubsection{Fort San Domingo as an image of exoticism}

Seth Mackay Ko (1900-1990) (柯設偕) is the son of the second daughter of the famous G. L. Mackay. During Japanese rule, Ko published books about Tamsui such as "the Poetic Beauty of Tamsui" (詩美の鄉淡水) and "the History of Tamsui” (淡水の歷史). Ko used the words “Jewish holy land", "Sea of Galilee," and the "Roman Colosseum" to describe the ancient buildings he saw. He wrote that Tamsui has the most foreign-like streets and exotic port while Fort San 
Domingo is just like Osaka and Kumamoto castle. The image of Fort San Domingo in his description are a beauty of exotic dream.

In the poem “Tamsui scenery: Fort San Domingo and sails” (淡水的景物— 紅毛城與帆船) he wrote, “....although Fort San Domingo is not as famous as Osaka castle where the Toyotomi clan was vanquished or the Kumamoto castle during the Satsuma Rebellion. Yet just like the people in Harima and Bizen who are proud of the castles of Himeji and Okayama, I too am proud of Fort San Domingo..." [20]. In the book, "Poetic beauty of Tamsui" he wrote, "...remember 300 years ago, the splendid dream of prosperity and joy in Fort San Domingo. I recalled the splendid old times and the magnificent north gate... Fort San Domingo has no legend like those castles of the River Rhine and no long history like the cathedral of Rotterdam. However, at the time of sunset the glowing red light shines behind the Fort, it is truly as remarkable as the Pyramid of Egypt! While the setting sun is still glowing, the Fort can be seen as Alhambra. When looking at Fort San Domingo, who can deny she is the defender of Tamsui?" [21].

Overall, Ko views the fort as he would a famous castle in Japan with exotic imagery. Clearly by the influence of Japanese rule, the fort is turned into a symbol of exotic image of culture and traveling.

\subsubsection{Fort San Domingo as an imagination of anti-imperialism}

The works of Yang Du and Li Shuang-ze are representative of this type.

In Yang Du’s (楊渡) poem “The Morning of Fort San Domingo” (紅毛城的 清晨), under the context of the Taiwanese local literature movement, he described Fort San Domingo as a symbol of anti-imperialism. He wrote,

"Through the thick fog and coast with sorrow and toil, it watched its people sail far away. Counting ships when they came back into Tamsui bay. Our broken family, our weakened mother." "And you, my lost brother, there is light coming back to Tamsui bay. The fishing boats are arrived. There are still anglers on the dawning shore. Fort San Domingo, our brother, when will you return to Tamsui bay. Return to our broken yet hardworking family" [12].

Li Shuang-ze (李雙澤) wrote a song about Fort San Domingo as he saw the Fort a symbol of imperialism. He wrote,

"Walked through many roads, the history we know is not marks of time. Unstopped imperialism for 300 years gave them treasures and left us with ruins. Fort San Domingo! Fort San Domingo! You are my witness. Fort San Domingo! Fort San Domingo! You are my homeland!” [22].

Overall, Fort San Domingo at that time and in that social context symbolized a national identity that needed to be taken back. 


\section{Conclusion}

This paper aims to analyze two aspects of the transformation of spatial use in Fort San Domingo and cultural imagination. My research methods include analysis of historical documents and works of text. Fort San Domingo was one of the earliest Grade I heritage sites first appointed under the Cultural Heritage Preservation Act in 1982. The Fort San Domingo transformation timeline shows it was used from the 1630s-1860s as a military defense then from 1860s-1970s as a foreign consulate and from 1980s-2010s as a historical site. The fort itself was originally a product of military settlement symbolizing a mark of European military and economic expansion through colonial conquest during the 17 th century. Later, it was transformed into a British consulate. We can see different and contradictory explanations of the cultural imagination of remembrance, exoticism and the symbolism of anti-imperialism from the historical context of this military building.

\section{References}

[1] Chang, C.Y., Historical and spatiotemporal transformation in Pudin and Piatou area, Tamsui, Lantai Press: Taipei, 2014.

[2] Huang, G., Discussions on the former British embassy in Tamsui. Taipei Document, 185, pp. 43-90, 2013.

[3] Yin, B,N., Cultural governance and heritage conservation: a case study of Fort Antonio, Tamsui, New Taipei City, 2013.

[4] Li, Y.Z., Spanish in Tamsui (1627-1637) - From the Great Navigation Epoch. Fort San Domingo Conference Proceedings, pp. 7-20, 2005.

[5] Anderson, B.R.O'G., Imagined communities: reflections on the origin and spread of nationalism, Verso: London, 1991.

[6] Tuan, Y.F., Topophilia: a study of environmental perception, attitudes, and values. Prentice-Hall: Englewood Cliffs, NJ, 1974.

[7] Tuan, Y.F., Space and Place: The Perspective of Experience. University of Minnesota Press: Minneapolis, MN, 1977.

[8] Cresswell, T., Place: A Short introduction. Wiley-Blackwell: Cornwall, 2004.

[9] Lefebvre, H., Space: social product and use value. Freiberg, J.W. (ed.), Critical Sociology: European Perspective. pp. 285-295. Irvington: New York, 1979.

[10] Taipei County Tamsui heritage museum, The Netherlands and Tamsui encounter - to reproduce the history of the Anthony Fort, 2006.

[11] Weng, J.I., The ancient map in Taipei, Taipei County Cultural Center published, p. 82, 1998,

[12] Taiwan University Civil Engineering Graduate School, The historic district program in Fort San Domingo in Tamsui, 1983.

[13] Lin, Z.H., History of Taiwan Foreign Relations, Sanmin Book Company: Taipei, p. 23, 1978. 
[14] Hideo Izumida, Initial British consulate architecture and engineering stations Shanghai office in Taiwan. Asian International Symposium on the History of Modern Architecture Proceedings, p. 2, 1989.

[15] Chou, S.Z., Spatiotemporal transformation in Tamsui during Japanese occupation, Unpublished $\mathrm{PhD}$ thesis. Department of Architecture, Tamkang University, p. 48, 1988.

[16] Huang, J.M., A history study of Tamsui British consul building during Japanese occupation. Fort San Domingo Conference Proceedings, pp. 73$105,2005$.

[17] Shen, Q.B. (ed.), Tamsui Town Records, Tamsui Town Hall: Taipei County, pp. 542-543, 1989.

[18] Taiwan Bank Economic Research Office, Tamsui Ting Zhi, p. 136, 1956,

[19] Nishikawa Mitsuru, Secret of Madam Liu, Zhang Liang-ze trans., United Daily News, 3 June, 1997.

[20] Ke, S.K., Tamsui scene - Fort San Domingo and sailing. Taiwan Xinmin newspaper, 1934.

[21] Ke, S.K., Poetic beauty in Tamsui, Tamsui in those days. Taipei: Chenwen Press, 1934.

[22] Liang, J.F. (ed.), Goodbye UK: Li shuang-ze's works, Longbridge Press: Taipei, p. 267, 1978.

[23] Xu, S.G. and Wu, M.C. (eds.), The authentic story of Taiwan: an illustrated history, Southern Book Company: Taipei, 1991.

[24] Record of historical documents of Japanese Ministry of Foreign Affairs, The Map of foreign community in Taiwan, Class 3, Part 12, Section 2, No. 33, 1897.

[25] Official documents of the Governor General of Taiwan, Buying lands of Tamsui British Consulate and the office buildings, 1897. 